\title{
KONSEKWENCJE PRZEKROCZENIA DOPUSZCZALNYCH POZIOMÓW EMISJI HAŁASU
}

\section{CONSEQUENCES OF EXCEEDING PERMISSIBLE NOISE LEVELS}

http://dx.doi.org/10.12775/PPOS.2016.014

\section{STRESZCZENIE}

Artykuł porusza temat konsekwencji prawnych przekroczenia dopuszczalnych poziomów emisji hałasu wynikających z ustawy Prawo ochrony środowiska z dnia 27 kwietnia 2001 r. W szczególności omówione zostały wyłączenia stosowania przepisów ustawy dotyczących ochrony przed hałasem w kontekście implementowanego prawa europejskiego. W dalszej kolejności autor omówił tryb, cele i skutki wydawania decyzji określającej dopuszczalne poziomy hałasu. Artykuł

* Magister, doktorant w Katedrze Prawa Ochrony Środowiska Wydziału Prawa i Administracji Uniwersytetu Jagiellońskiego. 
zawiera przemyślenia dotyczące wątpliwości prawnych dotyczących stosowania przepisów gwarantujących ochronę przed hałasem oraz wnioski dotyczące potrzeby zmiany obowiązujących przepisów.

\section{Słowa kluczowe}

Decyzja; hałas; ochrona; postępowanie; emisja; poziom.

\section{ABSTRACT}

The article focuses on legal consequences of exceeding permissible levels of noise emissions resulting from the Act of 27 April 2001 on environmental law. In particular, the author discusses the exclusion of the application of the Act concerning noise protection in the context of the implemented European law. Subsequently, the author discusses modes, targets and effects of issuing decisions determining permissible noise levels. The article contains reflections on questions concerning the application of rules guaranteeing protection against noise and proposals for necessary amendments to existing legislation.

\section{Keywords}

Decision; noise; protection; proceedings; emission; level.

\section{WSTĘP}

Zagadnienie ochrony prawnej przed hałasem zostało zakwalifikowane $\mathrm{w}$ ustawie Prawo ochrony środowiska ${ }^{1}$ jako element tzw. sektorowej ochrony środowiska. Przed przystąpieniem do omówienia środków ochrony prawnej przed hałasem wynikających z ww. ustawy, należy zastanowić się jednak nad definicją i znaczeniem hałasu w porządku prawnym. Polski ustawodawca podszedł do definicji hałasu od strony technicznej i w art. 3 pkt 5 u.p.o.ś. jako hałas

1 Ustawa z dnia 27 kwietnia 2001 r. Prawo ochrony środowiska, tekst jedn. Dz. U. z 2016 r., poz. 672 z późn. zm.; dalej jako: u.p.o.ś. 
określił dźwięki o określonej częstotliwości wyrażonej w hercach. Nie ulega jednak wątpliwości, że zgodnie z u.p.o.ś. hałas kwalifikuje się pod zakres pojęcia zanieczyszczenia określonego w słowniczku ustawowym jako emisja, która może być szkodliwa dla zdrowia ludzi lub stanu środowiska, może powodować szkodę $\mathrm{w}$ dobrach materialnych, może pogarszać walory estetyczne środowiska lub może kolidować z innymi, uzasadnionymi sposobami korzystania ze środowiska. Z kolei ustawodawca europejski w dyrektywie 2002/49/WE Parlamentu Europejskiego i Rady z dnia 25 czerwca 2002 r. odnoszącej się do oceny i zarządzania poziomem hałasu w środowisku², której implementację stanowią przepisy u.p.o.ś., wprowadza pojęcie „hałasu w środowisku”, którego definicja sprowadza się do stwierdzenia, że hałas to niepożądane lub szkodliwe dźwięki powodowane przez działalność człowieka na wolnym powietrzu, w tym hałas emitowany przez środki transportu, ruch drogowy, ruch kolejowy, ruch samolotowy, oraz hałas pochodzący z obszarów działalności przemysłowej ${ }^{3}$.

Ustalenie obowiązującej definicji hałasu ma znaczenie dla określenia czy wobec stwierdzonych naruszeń jednostce będzie przysługiwało prawo do skorzystania ze środków ochrony prawnej w drodze postępowania administracyjnego uregulowanego w u.p.o.ś. W tym aspekcie porównania wymagają zakresy wyłączeń zastosowania dyrektywy oraz u.p.o.ś. w związku z ochroną przeciwko hałasowi. Zgodnie z art. 2 ust. 2 dyrektywy, nie stosuje się jej do hałasu powodowanego przez osobę narażoną, hałasu powodowanego czynnościami domowymi, hałasu powodowanego przez sąsiadów, hałasu w miejscu pracy, hałasu wewnątrz środka transportu, ani hałasu powodowanego działaniami wojskowymi na terenach wojskowych. Dyrektywa znajduje natomiast zastosowanie do hałasu w środowisku, na jaki ludzie są narażeni, w szczególności na obszarach zabudowanych, w publicznych parkach lub na innych obszarach względ-

2 Dyrektywa 2002/49/WE Parlamentu Europejskiego i Rady odnosząca się do oceny i zarządzania poziomem hałasu w środowisku, Dz. Urz. UE L 189 z 18.7.2002, s. 12; dalej cyt.: dyrektywa 2002/49/WE.

3 Art. 3 pkt a dyrektywy 2002/49/WE. 
nie cichych $\mathrm{w}$ aglomeracji, na obszarach ciszy na otwartym terenie poza miastem, w pobliżu szkół, szpitali i innych wrażliwych na hałas budynków i obszarów. Z kolei u.p.o.ś., zgodnie $\mathrm{z}$ jej art. 2 ust. 2a, nie znajduje zastosowania w zakresie hałasu powstającego $\mathrm{w}$ związku z powszechnym korzystaniem ze środowiska, a więc bez wykorzystania instalacji, w celu zaspokojenia potrzeb osobistych oraz gospodarstwa domowego, w tym wypoczynku oraz uprawiania sportu. Jest to więc wyłączenie mniej precyzyjne, jednak dające się sprowadzić do wniosku, iż ochrona przed hałasem powodowanym przez osoby fizyczne korzystające ze środowiska w sposób powszechny, wyłączona jest spod regulacji ustawy u.p.o.ś., natomiast dotyczy ona podmiotów prowadzących działalność gospodarczą lub jednostek państwowych odpowiedzialnych za utrzymanie infrastruktury służącej np. transportowi.

\section{DOPUSZCZALNE POZIOMY HAEASU}

Ochrona prawna przed hałasem, zgodnie z art. 112 u.p.o.ś., polega na zapewnieniu jak najlepszego stanu akustycznego środowiska, w szczególności poprzez utrzymanie poziomu hałasu poniżej dopuszczalnego lub co najmniej na tym poziome oraz zmniejszenie poziomu hałasu do co najmniej dopuszczalnego, gdy nie jest on dotrzymywany.

Z uwagi na fakt, iż hałas jest zjawiskiem codziennym, którego źródła są rozproszone, konieczne jest wskazanie, że do kompetencji ministra właściwego do spraw środowiska działającego w porozumieniu z ministrem właściwym do spraw zdrowia, zostało powierzone określenie $\mathrm{w}$ drodze rozporządzenia, dopuszczalnego poziomu hałasu $\mathrm{w}$ środowisku, $\mathrm{z}$ zaznaczeniem konieczności kierowania się potrzebą zapewnienia należytej ochrony środowiska przed hałasem oraz mając na uwadze przepisy prawa Unii Europejskiej odnoszące się do oceny i zarządzania poziomem hałasu w środowisku. Dopuszczalne poziomy hałasu zostały uregulowane w rozporządzeniu Ministra Środowiska w sprawie dopuszczalnych poziomów hałasu 
$\mathrm{w}$ środowisku ${ }^{4}$. Zgodnie $\mathrm{z}$ delegacją ustawową poziomy hałasu zostały zróżnicowane wobec terenów: (1) pod zabudowę mieszkaniową, (2) pod szpitale i domy pomocy społecznej, (3) pod budynki związane ze stałym lub czasowym pobytem dzieci i młodzieży, (4) na cele uzdrowiskowe, (5) na cele rekreacyjno-wypoczynkowe, (6) pod zabudowę mieszkaniowo-usługową. Tym samym, ustawodawca wskazał wprost jakiego rodzaju tereny podlegają szczególnej ochronie przed hałasem.

Przywołane powyżej rodzaje terenów zgodnie z art. 114 ust. 1 u.p.o.ś. powinny być uwzględniane w miejscowych planach zagospodarowania przestrzennego. Jeżeli dany teren mógłby zostać zakwalifikowany do więcej niż jednego rodzaju, uznaje się, że dopuszczalne poziomy hałasu powinny być ustalone jak dla przeważającego rodzaju terenu. W razie braku miejscowego planu zagospodarowania przestrzennego oceny, czy teren należy do rodzajów terenów wymienionych w ustawie, dokonują właściwe organy na podstawie faktycznego zagospodarowania i wykorzystywania tego i sąsiednich terenów ${ }^{5}$. Wskazany w art. 115 u.p.o.ś. zwrot „właściwe organy” należy rozumieć $\mathrm{w}$ ten sposób, że $\mathrm{w}$ przypadku braku miejscowego planu zagospodarowania przestrzennego, organem właściwym do dokonania oceny, czy teren należy do rodzajów terenów, o których mowa w art. 113 ust. 2 pkt 1 u.p.o.ś. w postępowaniu prowadzonym na podstawie art. 115a ustawy, jest starosta ${ }^{6}$. Przepis art. 115a u.p.o.ś. nie przewiduje dla wydania przez starostę decyzji współdziałania z jakimkolwiek organem, a zatem stanowisko organu gminy co do faktycznego zagospodarowania i wykorzystania terenu nie posiada charakteru wiążącego, a co najwyżej może być brane pod uwagę tak jak każdy inny dowód podlegający ocenie organu decyzyjnego ${ }^{7}$.

4 Rozporządzenie Ministra Środowiska z dnia 14 czerwca 2007 r. w sprawie dopuszczalnych poziomów hałasu środowisku, tekst jedn. Dz. U. z 2014 r., poz. 112.

5 K. Gruszecki, Prawo ochrony środowiska. Komentarz, Warszawa 2016.

6 Wyrok WSA w Szczecinie z dnia 13 listopada 2008 r., sygn. akt: II Sa/Sz 116/08, CBOSA.

7 Wyrok NSA w Warszawie z dnia 19 marca 2010 r., sygn. akt: II OSK 524/09, CBOSA. 


\section{BRAK KONKRETYZACJI DOPUSZCZALNEGO POZIOMU EMISJ HAŁASU}

W przeciwieństwie do pozostałych rodzajów zanieczyszczeń tj. zanieczyszczenia powietrza czy wód, w przypadku emisji hałasu, dany inwestor nie ma obowiązku uzyskanie zezwolenia określającego warunki dozwolonej emisji. Normy hałasu nie są ustalane dla danej instalacji od czasu wejścia w życie nowelizacji art. 180 u.p.o.ś. z 2005 r. ${ }^{8}$, która z katalogu emisji powodujących konieczność uzyskania pozwolenia na eksploatację instalacji wykreśliła emitowanie hałasu oraz emitowanie pól magnetycznych przy jednoczesnym pozostawieniu wprowadzanie gazów lub pyłów do powietrza, wprowadzanie ścieków do wód lub do ziemi i wytwarzanie odpadów. Wynika z tego jednoznacznie, że to na prowadzącym instalację ciąży obowiązek ustalenia czy prowadzenie przez niego działalności będzie możliwe na danym terenie, ze względu na dopuszczalny poziom emisji hałasu określony w rozporządzeniu. Ma to szczególne znaczenie jeśli instalacja nie jest położona w strefie przemysłowej. Przykładem tego rodzaju instalacji okazały się bezdotykowe myjnie samochodowe czynne całą dobę, położone na terenach przeznaczonych pod zabudowę mieszkalno-usługową. O ile w przypadku uchwalenia miejscowego planu zagospodarowania przestrzennego prowadzący instalację ma możliwość zweryfikowania do jakiej kategorii został zakwalifikowany teren, na którym położona jest instalacja, tak w przypadku braku uchwalenia miejscowego planu zagospodarowania przestrzennego nie może on mieć pewności czy jego działalność będzie mieściła się w normach ustalonych w rozporządzeniu Ministra Środowiska. W szczególności ustawodawca nie przewidział mechanizmu, na mocy którego prowadzący instalację mógłby złożyć wniosek o dokonanie przez organ kwalifikacji danego terenu na podstawie faktycznego zagospodarowania i wykorzystywania tego i sąsiednich terenów. Nie ulega wątpliwości, że

8 Ustawa z dnia 18 maja 2005 r. o zmianie ustawy - Prawo Ochrony Środowiska oraz niektórych innych ustaw, Dz. U. z 2005 r. Nr 113, poz. 954. 
ocena faktycznego zagospodarowania i wykorzystania terenu ma charakter w pewnym sensie subiektywny, co rodzi ryzyko dla prowadzącego instalację.

\section{DECYZJA O DOPUSZCZALNYM POZIOMIE HAŁASU}

Zgodnie $\mathrm{z}$ art. 115a u.p.o.ś. $\mathrm{w}$ przypadku stwierdzenia przez organ ochrony środowiska, na podstawie pomiarów własnych, pomiarów dokonanych przez wojewódzkiego inspektora ochrony środowiska lub pomiarów podmiotu obowiązanego do ich prowadzenia, że poza zakładem, w wyniku jego działalności, przekroczone są dopuszczalne poziomy hałasu, organ ten wydaje decyzję o dopuszczalnym poziomie hałasu. W decyzji, określa on dopuszczalne poziomy hałasu poza zakładem przy zastosowaniu wskaźników hałasu i w odniesieniu do rodzajów terenów, na które oddziałuje zakład. Organem właściwym do wydania decyzji jest starosta, niekiedy również regionalny dyrektor ochrony środowiska lub marszałek województwa w przypadku przedsięwzięć mogących zawsze znacząco oddziaływać na środowisko.

Podkreślić należy, że wydanie decyzji o dopuszczalnym poziomie hałasu ma jedynie charakter deklaratoryjny, z uwagi na fakt, iż dopuszczalne poziomy hałasu obowiązują na danym terenie z mocy prawa. Oczywistym jest jednak, że wydanie przedmiotowej decyzji ma na celu otwarcie drogi do pociągnięcia prowadzącego instalację do odpowiedzialności administracyjnej lub karnej, o czym będzie mowa poniżej. Niemniej jednak należy zauważyć, że konstrukcja ta świadczy o tym, że wprowadzenie dopuszczalnego poziomu hałasu w drodze aktu prawa powszechnie obowiązującego odjęło wiele pracy organom administracji, jednak nie zagwarantowało pewności obrotu prawnego z uwagi na daleko idącą możliwość oceny przy określaniu rodzaju terenu, do którego przypisano konkretne, dopuszczalne poziomy emisji hałasu' ${ }^{9}$.

9 Z. Bukowski i in., Prawo ochrony środowiska. Komentarz, Warszawa 
Oczywistym jest, że powyższa interpretacja nie może być swobodna. W uzasadnieniu wydanej decyzji organ zobowiązany jest szczegółowo wyjaśnić na jakiej podstawie dokonał takiej a nie innej kwalifikacji danego terenu oraz jakie dowody lub pomiary przeprowadził na tę okoliczność. Zakres czynności podejmowanych $\mathrm{w}$ ramach postępowania $\mathrm{w}$ przedmiocie przekroczenia dopuszczalnego poziomu hałasu nie może ograniczać się wyłącznie do ustalenia, czy analizowany obszar może być zaliczony do któregoś albo kilku rodzajów terenów, ale materiał dowodowy musi również dokumentować, kto konkretnie był emitentem hałasu. Zebrane w sprawie dowody winny obrazować także jakim tytułem prawnym legitymuje się podmiot, prowadzący instalację emitującą hałas wraz z terenem na którym jest położona ${ }^{10}$. Trudności we wskazaniu emitenta hałasu mogą oczywiście wystąpić w przypadku gdy położenie instalacji stanowi zwarty kompleks oddziaływujący na sąsiednie nieruchomości.

Kluczowym jednak dowodem, który w każdym przypadku musi zostać przeprowadzony przez organ są pomiary. Pomiary te $\mathrm{z}$ racji konieczności posiadania fachowej wiedzy oraz sprzętu są przeprowadzane przez wojewódzkiego inspektora ochrony środowiska, na podstawie art. 9 ustawy o Inspekcji Ochrony Środowiska ${ }^{11}$. W konsekwencji, wydane na podstawie upoważnienia zawartego w przepisie art. 148 u.p.o.ś., rozporządzenie z dnia 30 października 2014 r. określające wymagania w zakresie prowadzenia pomiarów wielkości emisji o charakterze ciągłym i okresowym ${ }^{12}$, o których mowa w art. 147 ust. 1 i 2 u.p.o.ś., oraz pomiarów ilości pobieranej wody, o których mowa w art. 147 ust. 1, odnosi się również do emisji hałasu.

Trzeba mieć jednak na uwadze, że kontrola zgodnie $\mathrm{z}$ art. 12a ustawy o Inspekcji Ochrony Środowiska przeprowadzana

10 Wyrok NSA w Warszawie z dnia 13 marca 2012 r. II OSK 2486/10, CBOSA.

11 Ustawa z dnia 20 lipca 1991 r. o Inspekcji Ochrony Środowiska, tekst jedn. Dz. U. z 2013 r., poz. 686 z późn. zm.

12 Rozporządzenie Ministra Środowiska z dnia 30 października 2014 r. w sprawie wymagań w zakresie prowadzenia pomiarów wielkości emisji oraz ilości pobieranej wody, Dz. U. z 2014 r., poz. 1542. 
jest z uwzględnieniem rozdziału 5 ustawy o swobodzie działalności gospodarczej ${ }^{13}$. Oznacza to, że przed rozpoczęciem kontroli przedsiębiorca powinien zostać zawiadomiony o jej terminie. Katalog odstępstw od konieczności zawiadamiania przedsiębiorcy określony w art. 79 ust. 2 ustawy o swobodzie działalności gospodarczej nie przewiduje stricte przeprowadzenia kontroli emisji hałasu. Kontrola taka byłaby możliwa w przypadku uzasadnionym bezpośrednim zagrożeniem życia, zdrowia lub środowiska naturalnego. W przypadku jednak emisji hałasu, przesłanka ta co do zasady nie zawsze będzie mogła mieć zastosowanie z uwagi na charakter tej emisji.

Mając na względzie fakt, iż emisja hałasu zazwyczaj nie ma charakteru stałego, może być w sposób natychmiastowy zredukowana oraz nie zostawia mierzalnych śladów, w połączeniu z obowiązkiem zawiadomienia przedsiębiorcy o przeprowadzeniu kontroli może powodować niską skuteczność w wykrywaniu przez organ kontroli nadużyć w postaci przekraczania dozwolonych progów emisji hałasu. Wskazać w tym miejscy należy, że z dniem 1 lipca 2016 r. weszła w życie nowelizacja art. 79 ust. 2 ustawy o swobodzie działalności gospodarczej ${ }^{14}$, która umożliwia przeprowadzenie kontroli bez zapowiedzi czyli tzw. kontroli interwencyjnej, gdy jest przeprowadzana na podstawie przepisów ustawy o Inspekcji Ochrony Środowiska w zakresie poziomów pól elektromagnetycznych emitowanych z instalacji radiokomunikacyjnej, radionawigacyjnej lub radiolokacyjnej. Katalog ten nie został jednak rozszerzony o kontrolę poziomu emisji hałasu. $Z$ tego powodu, nasuwa się wniosek, że powinien on zostać rozszerzony, głównie z uwagi na fakt, iż przesłanka bezpośredniego zagrożenia życia, zdrowia lub środowiska naturalnego ma charakter zbyt ogólny i nie przystaje do specyfiki ochrony przed hałasem.

13 Ustawa z dnia 2 lipca 2004 r. o swobodzie działalności gospodarczej, tekst jedn. Dz. U. z 2015 r., poz. 584 z późn. zm.

14 Ustawa z dnia 9 czerwca 2016 r. o zmianie ustawy o wspieraniu rozwoju usług i sieci telekomunikacyjnych oraz niektórych innych ustaw, Dz. U. z 2016 r., poz. 903. 
W kontekście prowadzenia postępowania dowodowego przed wydaniem decyzji o dopuszczalnym poziomie hałasu, należy mieć na uwadze, że zgodnie z orzecznictwem sądów administracyjnych, do wydania decyzji o dopuszczalnym poziomie hałasu wystarczające jest już tylko jednorazowe przekroczenie dopuszczalnych norm ${ }^{15}$. W dalszej kolejności podkreślenia wymaga, że wykonanie pomiarów jako kluczowy dowód z punktu widzenia postępowania administracyjnego przeprowadzane jest jeszcze przed wszczęciem postępowania administracyjnego, co jest znaczącym odstępstwem od ogólnych zasad wynikających z kodeksu postępowania administracyjnego ${ }^{16}$.

Zauważyć należy, że w ramach omawianej decyzji organ ma również prawo wprowadzić m.in. określone wymagania mające na celu nieprzekraczanie poza zakładem dopuszczalnych poziomów hałasu, a w szczególności: (1) rozkład czasu pracy źródeł hałasu dla całej doby, wraz z przewidywanymi wariantami; (2) zakres, sposób i częstotliwość prowadzenia pomiarów poziomu hałasu w zakresie, w jakim wykraczają one poza wymagania; (3) formę, układ, techniki i termin przedkładania wyników pomiarów, organowi właściwemu do wydania decyzji i wojewódzkiemu inspektorowi ochrony środowiska. Szczególne znaczenia dla skuteczności ochrony przed hałasem ma możliwość nałożenia obowiązku wykonywania pomiarów, o czym będzie mowa poniżej.

\section{CEL WYDAWANIA DECYZJ 0 DOPUSZCZALNYM POZIOMIE HAEASU}

Mając na uwadze powyższe, należy zastanowić się jaki jest cel wydawania decyzji o dopuszczalnym poziomie hałasu. Otóż decyzja wydana na podstawie art. 115a u.p.o.ś. ma na celu

15 Wyrok NSA w Warszawie z dnia 24 lipca 2014 r. sygn. akt: II OSK $370 / 13$

16 Ustawa z dnia 14 czerwca 1960 r. Kodeks postępowania administracyjnego, tekst jedn. z 2016 r., poz. 23. 
ochronę otoczenia przed przekroczeniem przez dany podmiot dopuszczalnego poziomu hałasu. Decyzją wydaną w oparciu o art. 115a u.p.o.ś. organ określa takie normy dopuszczalnego poziomu hałasu, jakie wynikają z obowiązujących przepisów przywołanego rozporządzenia w sprawie dopuszczalnych poziomów hałasu w środowisku. W decyzji tej organ powinien stwierdzić, iż dany podmiot w związku ze swoją działalnością emituje hałas, który poza terenem działalności tego podmiotu przekroczył dopuszczalny poziom dla danego terenu i obliguje dany podmiot do zachowania obowiązujących w tym zakresie norm, nakładając dodatkowo obowiązek dokonywania pomiarów, kontrolujących zachowanie tych norm ${ }^{17}$.

Pewne kontrowersje przy wydawaniu przedmiotowej decyzji budził krąg potencjalnych stron postępowania, a w szczególności uznanie czy osoby poszkodowane przekraczaniem norm emisji hałasu, a więc znajdujący się w strefie oddziaływania instalacji, mogą zostać uznane za strony postępowania administracyjnego. Mając na uwadze cel wydawania decyzji, zakreślony powyżej, nie można mieć wątpliwości, że osoby znajdujące się strefie oddziaływania instalacji, mają zgodnie z art. 28 k.p.a. interes prawny w wydaniu omawianej decyzji. Ponadto z punktu widzenia praktyki, to najczęściej osoby poszkodowane są faktycznymi inicjatorami postępowania przed organem, chociaż zgodnie z art. 115a ust. 5 u.p.o.ś. postępowanie w tym przedmiocie jest wszczynane z urzędu. Stanowisko to potwierdził Naczelny Sąd Administracyjny w wyroku z dnia 15 października 2014 r. ${ }^{18}$, w którym przesądził, iż w postępowaniach prowadzonych na podstawie art. 115a u.p.o.ś. poszkodowana wspólnota mieszkaniowa ma uprawnienia strony. Może więc odwoływać się i kwestionować skierowaną do przedsiębiorcy decyzję ustalającą dopuszczalny poziom hałasu. Biorąc pod uwagę, że postępowanie w tej sprawie jest wszczynane wtedy, gdy zaistnieje uzasadnione podejrzenie przekroczeń, należy przyjąć, że inte-

17 Wyrok WSA w Gdańsku z dnia 10 września 2014 r., sygn. akt: II SA/Gd 249/14, CBOSA.

18 Wyrok NSA z dnia 15 października 2014 r., sygn. akt: II OSK 864/13, CBOSA. 
res prawny w rozumieniu art. 28 k.p.a. będą miały co najmniej wszystkie podmioty położone $\mathrm{w}$ bezpośrednim sąsiedztwie obiektu, z działalnością którego wiąże się emisja hałasu. Omawiany rodzaj decyzji jest wydawany w celu zapewnienia tym podmiotom odpowiednich warunków życia lub prowadzenia innego rodzaju działalności. Natomiast adresatem takiej decyzji może być tylko podmiot, którego działalność stanowi źródło emisji hałasu.

W dalszej kolejności należy zauważyć, że przedmiotowa decyzja wydawana jest niejako na czas nieokreślony. Może ona natomiast zostać zmieniona na podstawie art. 115a ust. 7 u.p.o.ś., stanowiącej lex specialis w stosunku do przepisów k.p.a., w następujących przypadkach: (1) uchwalenia albo utraty mocy obowiązującej miejscowego planu zagospodarowania przestrzennego dotyczącego terenów objętych oddziaływaniem hałasu z zakładu; (2) zmiany faktycznego zagospodarowania i wykorzystania nieruchomości, na które oddziałuje hałas z zakładu, nieobjętych miejscowym planem zagospodarowania przestrzennego; (3) zmiany obowiązujących dopuszczalnych poziomów hałasu. Postępowanie w sprawie zmiany decyzji wszczynane jest z urzędu.

\section{WYŁĄCZENIA MOŻLIWOŚCI WYDANIA DECYZJI O DOPUSZCZALNYM POZIOMIE HAŁASU}

Co ciekawe jednak, zgodnie z art. 115a ust 2 u.p.o.ś. jeżeli hałas powstaje w związku z eksploatacją dróg, linii kolejowych, linii tramwajowych, kolei linowych, portów oraz lotnisk lub w związku z działalnością osoby fizycznej niebędącej przedsiębiorcą, decyzji, o dopuszczalnym poziomie hałasu, nie wydaje się. Oznacza to, że wszczęte postępowanie administracyjne powinno zostać umorzone jako bezprzedmiotowe ${ }^{19}$. Na wymienionej liście znajdują się przede wszystkim inwestycje związane

19 Wyrok WSA w Krakowie z dnia 7 października 2011 r., II SA/Kr 999/11, CBOSA. 
z transportem, w tym głównie inwestycje liniowe. Wyłączenie osoby fizycznej nieprowadzącej działalności gospodarczej wpisuje się w przywołany na wstępie katalog wyłączeń określony w dyrektywie. W kontekście powyższego nasuwa się pytanie, czy osoby poszkodowane przekraczaniem poziomu dopuszczalnych emisji nie mogą korzystać z ochrony swoich praw przed organem administracji publicznej?

W przypadku wymienionych inwestycji ciężar należytej ochrony przed hałasem został przesunięty w stronę przepisów wykonawczych regulujących warunki techniczne wykonania inwestycji lub jej eksploatacji. Najlepiej zobrazować to zagadnienie na przykładzie dróg. W $\S 177$ rozporządzenia Ministra Transportu i Gospodarki Morskiej w sprawie warunków technicznych, jakim powinny odpowiadać drogi publiczne i ich usytuowanie ${ }^{20}$ przewidziano, że przy projektowaniu drogi powinno się dążyć do tego, aby w jej otoczeniu obliczeniowe poziomy hałasu i wibracji powodowane prognozowanym ruchem na drodze nie przekraczały wartości dopuszczalnych określonych w przepisach odrębnych. Natomiast jeżeli prognozowane poziomy hałasu i wibracji przekraczają wartości dopuszczalne określone w przepisach odrębnych, przy projektowaniu drogi powinno się zaplanować zastosowanie odpowiednich środków ochrony. Urządzenia ochrony przed hałasem i wibracjami mogą być także zastosowane po wybudowaniu drogi w wypadku stwierdzenia przekroczenia dopuszczalnych poziomów hałasu i wibracji. Oznacza to, że na etapie projektowania inwestycji drogowej tj. w procedurze wydawania decyzji o środowiskowych uwarunkowaniach, o lokalizacji inwestycji celu publicznego lub decyzji zezwalającej na budowę, zainteresowane osoby mogą kwestionować brak odpowiednich zabezpieczeń przed hałasem. W przypadku natomiast inwestycji już funkcjonującej, zainteresowane osoby mogą domagać się realizacji przez władzę publiczną swoich obowiązków wynikających z dopuszczalnych

20 Rozporządzenie Ministra Transportu i Gospodarki Morskiej z dnia 2 marca 1999 r. w sprawie warunków technicznych, jakim powinny odpowiadać drogi publiczne i ich usytuowanie, tekst jedn. Dz. U. z 2016 r., poz. 124. 
poziomów emisji hałasu ${ }^{21}$. Nadmienić jedynie należy również, że jednostka ma możliwość obrony swoich interesów również w procedurze ustanowienia obszaru ograniczonego użytkowania lub poprzez kierowanie roszczeń odszkodowawczych.

\section{DALSZE KONSEKWENCJE WYDANIA DECYZJI O DOPUSZCZALNYM POZIOMIE HAŁASU}

Jak to było sygnalizowane już wcześniej, wydanie decyzji o dopuszczalnym poziomie hałasu, nie wyczerpuje kwestii odpowiedzialności prowadzącego instalację za przekroczenie poziomu emisji hałasu. Po pierwsze należy zauważyć, że zgodnie z art. 298 ust. 1 pkt 5 u.p.o.ś. wojewódzki inspektor ochrony środowiska za przekroczenie określonego w decyzji dopuszczalnego poziomu hałasu, nakłada karę pieniężną. Przesłanką odpowiedzialności finansowej jest więc wydanie decyzji o dopuszczalnym poziomie hałasu. Za przekroczenie dopuszczalnych poziomów emisji przed wydaniem decyzji, administracyjna kara pieniężna nie może zostać nałożona. Nie mniej jednak wojewódzki inspektor ochrony środowiska ma obowiązek nałożyć wobec prowadzącego instalację także tzw. karę biegnącą, która ma na celu zmotywowanie do jak najszybszego usunięcia naruszeń. Zgodnie z art. 315 ust. 1 u.p.o.ś. kary, wymierza się odrębnie dla pory dnia i pory nocy. Prowadzący instalację, który narusza warunki decyzji o dopuszczalnym poziomie hałasu podlega karze aresztu albo ograniczenia wolności albo karze grzywny.

Istotną i dotkliwą konsekwencją wydania decyzji o dopuszczalnym poziomie emisji hałasu jest określenie w niej zakresu, sposobu i częstotliwość prowadzenia pomiarów poziomu

21 Patrz - wyrok NSA z dnia 17 czerwca 2011 r., II OSK 1057/10, w którym NSA stwierdził, iż okoliczność, że przekroczenie dopuszczalnego poziomu hałasu pozostaje w związku z eksploatacją drogi nie wyłącza zastosowania środków prawnych przewidzianych w art. 362 u.p.o.ś. oraz, że przepis art. 362 u.p.o.ś. ma charakter uzupełniający i powinien być stosowany wówczas, gdy inne normy nie przewidują bardziej szczegółowych rozwiązań. 
hałasu w zakresie, w jakim wykraczają one poza standardowe obowiązki pomiarowe wynikające z art. 147-148 u.p.o.ś. oraz formę, układ, techniki i termin przedkładania wyników pomiarów. Zgodnie $\mathrm{z}$ art. 115a ust. 4 u.p.o.ś., są to elementy fakultatywne decyzji, niemniej jednak mają one istotny charakter zapobiegający przekraczaniu poziomu emisji hałasu w przyszłości. Trzeba mieć jednak na uwadze, że nałożenie w decyzji dodatkowego obowiązku na stronę (prowadzącego instalację) wymaga szczegółowego uzasadnienia jego celowości i nie może być stosowane automatycznie do każdego przypadku.

Konkludując, wydanie decyzji o dopuszczalnym poziomie hałasu, należy traktować jako ostrzeżenie, które w przypadku niezastosowania się do jej postanowień otwiera drogę do pociągnięcia podmiotu naruszającego poziomy emisji hałasu do odpowiedzialności bardziej dotkliwej oraz może nakładać na niego dalej idące obowiązki np. w zakresie wykonywania pomiarów i sprawozdawczości.

\section{PODSUMOWANIE}

Hałas jest zakłóceniem nieprzyjemnym i z całą pewnością szkodliwym dla zdrowia człowieka. Zmniejsza on wydajność pracy, utrudnia wypoczynek i koncentrację. Jest więc jednym z kluczowych czynników decydujących o komforcie życia ${ }^{22}$. Społeczeństwo powinno posiadać skuteczne narzędzie w walce o zapewnienie komfortu życia i usunięcia naruszeń zagrażających ich zdrowiu. Z drugiej strony prowadzący instalację powinni mieć pewność czy ich działania nie naruszają dopuszczalnych norm emisji hałasu. Wynikają z tego dwa wnioski de lege ferenda. Pierwszy dotyczy uprawnienia organów inspekcji środowiska w przeprowadzaniu kontroli bez konieczności wcześniejszego zawiadamiania w każdym przypadku gdy weryfikowane są poziomy emisji hałasu, bez konieczności wykazywania, że prze-

22 Prawo ochrony środowiska, J. Stelmasiak (red.), Warszawa 2010, s. 279. 
prowadzenie kontroli jest uzasadnione bezpośrednim zagrożeniem życia, zdrowia lub środowiska naturalnego oraz drugi w postaci wprowadzenia mechanizmu pozwalającego inwestorowi na uzyskanie decyzji określającej dopuszczalne poziomy emisji hałasu w przypadku gdy na danym terenie nie uchwalono miejscowego planu zagospodarowania przestrzennego.

\section{BIBLIOGRAFIA}

Gruszecki K., Prawo ochrony środowiska. Komentarz, Warszawa 2016.

Bukowski Z. i in., Prawo ochrony środowiska. Komentarz, Warszawa 2013.

Prawo ochrony środowiska, J. Stelmasiak (red.), Warszawa 2010.

Kontakt e-mail:

kocol.tomasz@gmail.com 